\title{
Incidence of cervical cancer by marital status
}

\author{
IAN LECK, KAY SIBARY, AND JOHN WAKEFIELD*
}

From the Regional Cancer Epidemiology Unit and the Department of Social Research, University Hospital $\vec{\nexists}$ of South Manchester; Christie Hospital and Holt Radium Institute, Manchester; and the Department of $\stackrel{5}{?}$ Community Medicine, University of Manchester

SUMMARY The incidence of invasive cervical cancer by age and marital status was examined, using census statistics and 1968-71 cancer registry data for women who lived in the Manchester Regional Hospital Board area. The relative rarity of the disease in the unmarried and its higher incidence in $\stackrel{\circ}{.}$ formerly married than in currently married women was confirmed. This higher incidence was shown $\overrightarrow{\vec{\omega}}$ to be mainly in widows under 50 and divorced women, suggesting that it is related to the association $\stackrel{\rho}{s}$ of the disease with number of sexual partners.

The risks of developing invasive cancer of the uterine cervix, or carcinoma in situ, seem to be higher for married than for single women, and higher still for the formerly married. Although age-standardisation weakens this trend, it does not abolish it. The trend has been observed in national statistics of cervical cancer mortality (Registrar General, 1964); in studies of the distribution of abnormal smears among those screened for the disease (Sansom et al., 1971; Cooper and Hillier, 1975); and in case-control studies of patients with cervical cancer (for example, Lombard and Potter, 1950; Terris and Oalmann, 1960; Boyd and Doll, 1964; Martin, 1967; and Pridan and Lilienfeld, 1971).

Given the association of cervical cancer with number of sexual partners (Terris and Oalmann, 1960; Martin, 1967; Rotkin, 1967; Pridan and Lilienfeld, 1971), we should not expect the high rate of the disease in the formerly married to apply equally to both widowed and divorced women. Few attempts, however, have been made to determine whether this is so. In Denmark, Grünfeld et al. (1975) showed that divorced women had higher death rates from cervical cancer than widows. In Aberdeenshire, Aitken-Swan and Baird (1966) found substantially more divorced women and only slightly more widows in a group with carcinoma in situ than in a matched control group. By contrast, among Jewish women in Israel with cervical cancer, Pridan and Lilienfeld (1971) found substantially more widows as well as more who had been divorced than in a control group.

*Dr Wakefield died on 10 January 1978
In the last two studies figures were not available $\stackrel{N}{\rightarrow}$ for the whole related population, and the study by $\infty$ Grünfeld et al. (1975) did not include non-fatal cases. 을 In an attempt to remedy these deficiencies, the incidence of registered cases of invasive cervical $c$ cancer by marital status in a defined population ha्大 been examined.

\section{Material}

All hospital cases of invasive cervical cancer in residents of the former Manchester Regional o Hospital Board area registered for the years 1968-71 under the National Cancer Registration Scheme were $\stackrel{\mathbb{Q}}{\square}$ ascertained from the records of the Regional Cancer $\overrightarrow{\vec{O}}$ Registry. The records for 1968-71 were selected in 3

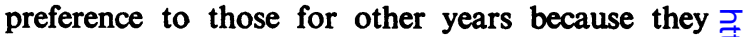
included adequate data on marital status as well as age. Population estimates by marital status and age for the end of 1969 (the midpoint of the period $\stackrel{\odot}{)}$ when the cases presented) were derived by linear 0 interpolation from the 1961 and 1971 census data for all local authorities in the Manchester Regional of Hospital Board area.

\section{Methods}

Overall and age-specific incidence rates of invasive cervical cancer were calculated for each marital o status group. Age-specific rates for the whole $N$ population (excluding cases of unknown marital N status) were also computed. An indirect age- $\omega$ standardisation was then carried out, firstly, by applying the latter rates to the observed age $\stackrel{0}{=}$ distribution of each group, so as to determine the $\stackrel{\Phi}{\rightarrow}$ 
Table 1 Frequency of invasive cervical cancer by marital status and age: Manchester Regional Hospital Board area, $1968-71$

\begin{tabular}{|c|c|c|c|c|c|c|c|c|c|c|c|c|}
\hline \multirow{3}{*}{$\begin{array}{l}\text { Age } \\
\text { (years) }\end{array}$} & \multicolumn{2}{|l|}{ Single } & \multicolumn{2}{|l|}{ Married } & \multicolumn{2}{|l|}{ Widows } & \multicolumn{2}{|c|}{ Divorced } & \multicolumn{3}{|c|}{ Women of specified marital status } & \multirow{3}{*}{$\begin{array}{l}\text {-Women of } \\
\text { unspecified } \\
\text {-marital status } \\
\text { (No. of cases) }\end{array}$} \\
\hline & \multirow{2}{*}{$\begin{array}{l}\text { Popula- } \\
\text { tion }\end{array}$} & \multirow{2}{*}{$\begin{array}{l}\text { No. of } \\
\text { cases }\end{array}$} & \multirow{2}{*}{$\begin{array}{l}\text { Popula- } \\
\text { tion }\end{array}$} & \multirow{2}{*}{$\begin{array}{l}\text { No. of } \\
\text { cases }\end{array}$} & \multirow{2}{*}{$\begin{array}{l}\text { Popula- } \\
\text { tion }\end{array}$} & \multirow{2}{*}{$\begin{array}{l}\text { No. of } \\
\text { cases }\end{array}$} & \multirow{2}{*}{$\begin{array}{l}\text { Popula- } \\
\text { tion }\end{array}$} & \multirow{2}{*}{$\begin{array}{l}\text { No. of } \\
\text { cases }\end{array}$} & \multirow{2}{*}{$\begin{array}{l}\text { Popula- } \\
\text { tion }\end{array}$} & \multicolumn{2}{|c|}{ Cases registered } & \\
\hline & & & & & & & & & & No. & Incidence* & \\
\hline $\begin{array}{l}20-24 \\
25-29 \\
30-34 \\
35-39 \\
40-44 \\
45-49 \\
50-54 \\
55-59 \\
60-64 \\
65-69 \\
70-74 \\
75-79 \\
80-84 \\
85-89 \\
90 \text { \& over }\end{array}$ & $\begin{array}{r}62.2 \\
16.9 \\
9.7 \\
9.0 \\
9.9 \\
11.9 \\
12.8 \\
15.5 \\
18.6 \\
19.0 \\
16 \cdot 2 \\
12.0 \\
7.3 \\
3 \cdot 1 \\
1.0\end{array}$ & $\begin{array}{r}4 \\
1 \\
3 \\
4 \\
9 \\
4 \\
18 \\
12 \\
10 \\
7 \\
4 \\
5 \\
2 \\
1 \\
1\end{array}$ & $\begin{array}{r}100 \cdot 1 \\
120 \cdot 0 \\
116 \cdot 2 \\
114 \cdot 2 \\
119 \cdot 5 \\
128 \cdot 0 \\
115 \cdot 7 \\
110 \cdot 5 \\
94 \cdot 8 \\
66 \cdot 7 \\
39 \cdot 3 \\
18 \cdot 1 \\
6 \cdot 1 \\
1 \cdot 3 \\
0 \cdot 2\end{array}$ & $\begin{array}{r}12 \\
20 \\
47 \\
81 \\
156 \\
238 \\
247 \\
212 \\
138 \\
102 \\
59 \\
20 \\
3 \\
1 \\
1\end{array}$ & $\begin{array}{r}0 \cdot 2 \\
0 \cdot 4 \\
0 \cdot 8 \\
1 \cdot 6 \\
3 \cdot 5 \\
7 \cdot 3 \\
12 \cdot 6 \\
22 \cdot 8 \\
35 \cdot 3 \\
46 \cdot 5 \\
53 \cdot 4 \\
46 \cdot 1 \\
31 \cdot 9 \\
14 \cdot 6 \\
4 \cdot 7\end{array}$ & $\begin{array}{r}0 \\
0 \\
1 \\
1 \\
7 \\
20 \\
22 \\
40 \\
57 \\
75 \\
71 \\
58 \\
23 \\
10 \\
5\end{array}$ & $\begin{array}{l}0 \cdot 9 \\
2 \cdot 5 \\
3 \cdot 3 \\
3 \cdot 3 \\
3 \cdot 1 \\
3 \cdot 0 \\
2 \cdot 2 \\
2 \cdot 7 \\
2 \cdot 5 \\
1 \cdot 0 \\
0 \cdot 3 \\
0 \cdot 3 \\
0 \cdot 3 \\
0 \cdot 1 \\
0 \cdot 0\end{array}$ & $\begin{array}{r}0 \\
4 \\
6 \\
0 \\
7 \\
13 \\
14 \\
3 \\
2 \\
0 \\
0 \\
0 \\
0 \\
0 \\
0\end{array}$ & $\begin{array}{r}163.4 \\
139.8 \\
130.0 \\
127.9 \\
135.9 \\
150.4 \\
143.8 \\
151 \cdot 3 \\
150 \cdot 7 \\
133.5 \\
109.5 \\
76.5 \\
45.4 \\
19.0 \\
5.9\end{array}$ & $\begin{array}{r}16 \\
25 \\
57 \\
86 \\
179 \\
275 \\
301 \\
267 \\
207 \\
184 \\
134 \\
83 \\
28 \\
12 \\
7\end{array}$ & $\begin{array}{r}2 \cdot 4 \\
4 \cdot 5 \\
11 \cdot 0 \\
16 \cdot 8 \\
32 \cdot 9 \\
45 \cdot 7 \\
52 \cdot 3 \\
44 \cdot 1 \\
34 \cdot 3 \\
34 \cdot 5 \\
30 \cdot 6 \\
27 \cdot 1 \\
15 \cdot 4 \\
15 \cdot 8 \\
29 \cdot 7\end{array}$ & $\begin{array}{l}0 \\
1 \\
0 \\
1 \\
3 \\
8 \\
5 \\
5 \\
4 \\
6 \\
6 \\
4 \\
2 \\
2 \\
0\end{array}$ \\
\hline All & $225 \cdot 1$ & 85 & $1150 \cdot 7$ & 1337 & $281 \cdot 7$ & 390 & $25 \cdot 5$ & 49 & $1683 \cdot 0$ & 1861 & $27 \cdot 6$ & 47 \\
\hline
\end{tabular}

Population in thousands

* Per 100000 woman years

Table 2 Incidence of invasive cervical cancer by marital status, Manchester Regional Hospital Board area, 1968-71

\begin{tabular}{lcccl}
\hline $\begin{array}{l}\text { Marital } \\
\text { status }\end{array}$ & $\begin{array}{l}\text { No. } \\
\text { observed }\end{array}$ & $\begin{array}{l}\text { Crude annual rate } \\
\text { per million women } \\
\text { aged 20 or over }\end{array}$ & $\begin{array}{l}\text { No. } \\
\text { expected }\end{array}$ & $\begin{array}{l}\text { Standardised } \\
\text { incidence } \\
\text { ratio }\end{array}$ \\
\hline Single & 85 & 94 & $200 \cdot 6$ & $0 \cdot 42$ \\
Married & 1337 & 290 & $1282 \cdot 3$ & 1.04 \\
Widows & 390 & 346 & $348 \cdot 5$ & 1.12 \\
Divorced & 49 & 480 & 29.6 & 1.66 \\
\hline
\end{tabular}

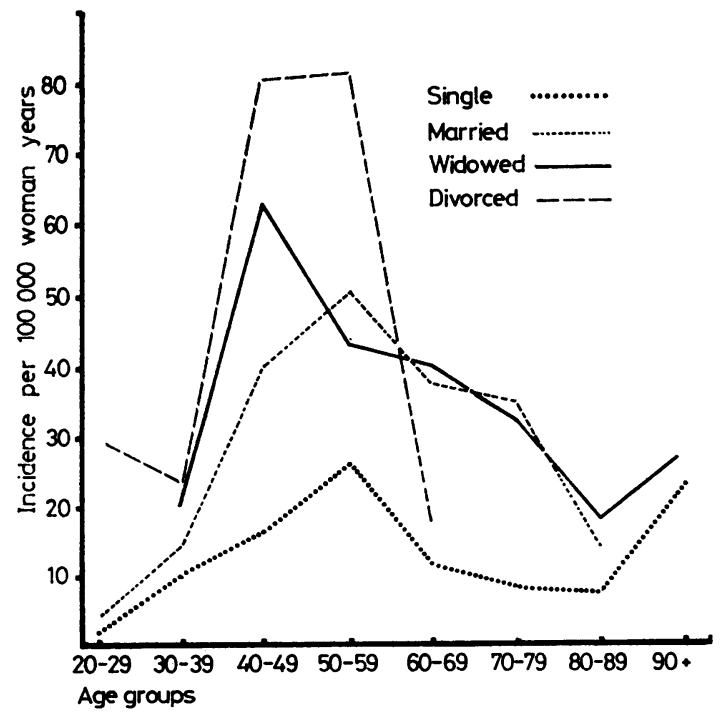

Figure Age specific incidence rates of invasive cervical cancer by marital status. number of cases that would have been expected in that group if marital status were unrelated to frequency; and, secondly by calculating the ratio of the observed to the expected number of cases for each marital group.

\section{Results}

The basic data for each group are set out in Table 1. The corresponding crude incidence rates and standardised incidence ratios (Table 2) are not very different for the married and widowed but much higher for the divorced. However, an analysis of incidence by age (Figure) shows that widows are at considerably higher risk than married women under the age of 50-a difference to which the standardisation procedure gave little weight because the proportion of widows below that age was very small. The incidence was highest at the ages of 40 to $\mathbf{4 9}$ for widows and at 50 to 59 for the other marital groups, although the rate for divorced women was almost as high in the former age group as it was in the latter.

\section{Discussion}

The obvious limitations of these data are the incompleteness of cancer registration and the probability that some divorced women misrepresented their marital status. Both factors are likely to have affected mainly the figures for older women. Nevertheless, it seems clear that the increased incidence of cervical cancer among women with broken marriages is mainly found in the divorced and young widows. The difference between their 
incidence rates and those for the currently married women might have been even more marked if it had been possible to exclude from the latter group the remarried women and those separated from their husbands.

We conclude that the high rates of the disease in formerly married women are probably related to its association with number of sexual partners (Terris and Oalmann, 1960; Martin, 1967; Rotkin, 1967: Pridan and Lilienfeld, 1971), rather than to the psychosomatic effects of bereavement from loss of husband through death or divorce as suggested by Le Shan and Worthington (1956), Schmale and Iker (1966), and Rees and Lutkins (1967).

Addendum. Since this paper was written, incidence rates for registered cases of cervical cancer in Israeli Jews have been published (Sharon et al., 1977). These rates were higher for divorced women and lower for widows than for the currently married, both under and over the age of 50; but the number of cases analysed was relatively small.

Kay Sibary was supported by a grant from the Department of Health and Social Security for this study.

Reprints from: Ian Leck, Regional Cancer Epidemiology Unit, University Hospital of South Manchester Christie Hospital and Holt Radium Institute, Manchester M20 9BX.

\section{References}

Aitken-Swan, J., and Baird, D. (1966). Cancer of the uterine cervix in Aberdeenshire. Aetiological aspects. British Journal of Cancer, 20, 642-655.
Boyd, J. T., and Doll, R. (1964). A study of the aetiology of carcinoma of the cervix uteri. British Journal of Cancer, 18, 419-433.

Cooper, A. G., and Hillier, V. F. (1975). Some characteristics of women with abnormal cervical cytological $T$ findings. Public Health, 89, 213-221.

Grünfeld, K., Horwitz, D., and Lusgaard Hansen, B. (1975). Evaluation of mortality data for cervical cancer with special reference to mass screening programmes. American Journal of Epidemiology, 101, 265-275.

Le Shan, L., and Worthington, R. E. (1956). Some recurrent life history patterns observed in patients $\overline{\bar{c}}$ with malignant disease. Journal of Nervous and $\underset{\mathbb{D}}{\vec{D}}$ Mental Diseases, 124, 460-473.

Lombard, H., and Potter, E. (1950). Epidemiological ఝ aspects of cancer of the cervix. Cancer, 3, 960-967.

Martin, C. E. (1967). Marital and coital factors in. cervical cancer. American Journal of Public Health, $\overrightarrow{\vec{\omega}}$ 57, 803-814.

Pridan, H., and Lilienfeld, A. M. (1971). Carcinoma of $\frac{}{\overparen{ }}$ the cervix in Jewish women in Israel, 1960-67. Israel $\stackrel{\Omega}{S}$ Journal of Medical Science, 7, 1465-1470.

Rees, W. D., and Lutkins, S. G. (1967). Mortality of N bereavement. British Medical Journal, 4, 13-16.

Registrar General (1964). Malignant neoplasms of the $\vec{\circ}$ genital organs according to marital condition. $\infty$ Registrar General's Statistical Review of England and Wales for the year 1961. Part III: Commentala , pp. 209-221. HMSO: London.

Rotkin, I. D. (1967). Sexual characteristics of a cervis్b̂l. cancer population. American Journal of Public Heali,

Sansom, C. D., Wakefield, J., and Yule, R. (197).. Trends in cytological screening in the Manchester $\square$ area, 1965 to 1971. Community Medicine, 126, 253-257.

Schmale, A. H., and Iker, H. P. (1966). The affect of hopelessness and the development of cancer. Psycho-O somatic Medicine, 28, 714-721.

Sharon, Z., Shani, M., and Modan, B. (1977). Clinico-@ epidemiologic study of uterine cancer: comparative $\overrightarrow{\bar{O}}$ aspects of the endometrial and cervical sites. Obstetrics 3 and Gynecology, 50, 536-40.

Terris, M., and Oalmann, M. C. (1960). Carcinoma of the cervix. Journal of the American Medical Association 174, 1847-1851. 